\title{
Activation of the Nuclear Factor $\kappa B$ pathway by heavy ion beams of different linear energy transfer
}

\author{
Christine E. Hellweg ${ }^{1}$, Christa Baumstark-Khan ${ }^{1}$, Claudia Schmitz ${ }^{1}$, Patrick Lau' ${ }^{1}$, Matthias M. Meier ${ }^{1}$, \\ Isabelle Testard ${ }^{2}$, Thomas Berger ${ }^{1} \&$ Günther Reitz ${ }^{1}$ \\ ${ }^{1}$ German Aerospace Centre (DLR), Institute of Aerospace Medicine, Radiation Biology, Linder Höhe, Köln, Germany, and \\ ${ }^{2}$ Laboratoire d'Accueil en Radiobiologie avec les lons Accélérés (LARIA), CEA, DVS/IRCM/SRO at the Centre de recherches sur les \\ Ions, les Matériaux et la Photonique (CIMAP)/Grand Accélérateur National d'Ions Lourds (GANIL), Caen Cedex, France
}

\begin{abstract}
Purpose: Risk assessment of radiation exposure during long-term space missions requires the knowledge of the relative biological effectiveness (RBE) of space radiation components. Few data on gene transcription activation by different heavy ions are available, suggesting a dependence on linear energy transfer. The transcription factor Nuclear Factor $\kappa \mathrm{B}(\mathrm{NF}-\kappa \mathrm{B})$ can be involved in cancerogenesis. Therefore, NF- $\kappa B$ activation by accelerated heavy ions of different linear energy transfer (LET) was correlated to survival.

Materials and methods: NF- $\kappa \mathrm{B}-$ dependent gene induction after exposure to heavy ions was detected in stably transfected human embryonic kidney 293 cells (HEK-pNF-KB-d2EGFP/Neo cells carrying a neomycin resistance), using the destabilized Enhanced Green Fluorescent Protein (d2EGFP) as reporter.

Results: Argon (LET $272 \mathrm{keV} / \mu \mathrm{m}$ ) and neon ions (LET $91 \mathrm{keV} / \mu \mathrm{m}$ ) had the highest potential to activate NF- $\kappa B$, resulting in a RBE of 8.9 in comparison to $150 \mathrm{kV}$ X-rays. The RBE for survival also reached its maximum in this LET range, with a maximal value of 2 . Conclusions: NF- $\mathrm{KB}$ might be involved in modulating survival responses of cells hit by heavy ions in the LET range of 91-272 $\mathrm{keV} / \mu \mathrm{m}$ and could therefore become a factor to be considered for risk assessment of radiation exposure during space travel.
\end{abstract}

Keywords: Nuclear Factor $\kappa B$, linear energy transfer, heavy ion, space mission, relative biological effectiveness

Abbreviations: bcl-2, B-cell lymphoma 2; bcl-XL, B-cell lymphomaextra large; CDKN1A, Cyclin-dependent kinase inhibitor $1 \mathrm{~A} ; \mathrm{CHO}$, Chinese Hamster Ovary; CIMAP, Centre de recherches sur les Ions, les Matériaux et la Photonique; d2EGFP, destabilized EGFP; EGFP, Enhanced Green Fluorescent Protein; FBS, fetal bovine serum; GANIL, Grand Accélérateur National d'lons Lourds; HEK, human embryonic kidney; IAP, inhibitor of apoptosis protein; I $\kappa \mathrm{B} \alpha$, inhibitor of NF- $\kappa \mathrm{B} \alpha$; LARIA, Laboratoire d'Accueil en Radiobiologie avec les lons Accélérés; LET, linear energy transfer; $\mathrm{MeV} / \mathrm{n}$, Mega electron Volt per nucleon; NASA, National Aeronautics and Space Administration (USA); NCRP, National
Council on Radiation Protection and Measurements; NF- $\kappa B$, Nuclear Factor $\kappa B$; RBE, relative biological effectiveness; Rel, Reticuloendotheliosis; TK, thymidine kinase; TNF- $\alpha$, tumor necrosis factor $\alpha$; TP53, tumor protein p53; DNA-PK, DNAdependent protein kinase.

\section{Introduction}

The radiation environment that astronauts experience during spaceflight differs significantly to that found on Earth (Straube et al. 2010). Besides protons and $\alpha$-particles, heavier nuclei are part of the radiation field encountered in space. Although heavy nuclei only make up about $2 \%$ of the fluence in space, they will account for much of the biological consequences due to their higher linear energy transfer (LET) (Pecaut and Gridley 2010). Primarily late tissue sequelae like genetic alterations, cancer and non-cancer effects are the potential risks resulting from radiation exposure in deep space (Blakely 2000). Due to mass limitations for spacecrafts and production of secondary particles in shielding material, the radiation exposure cannot simply be avoided by radiation shielding of the spacecraft (National Council on Radiation Protection and Measurements [NCRP] 2006). The prolonged exposure to galactic cosmic rays requires extensive further study of the biological effects of these extraordinary radiation qualities and quantities in order to improve the estimation of health effects of radiation exposures on humans during and after exploration missions (Cucinotta et al. 2005, NCRP 2006, Hellweg and Baumstark-Khan 2007).

In the cellular response to radiation, several sensors detect the induced DNA damage and trigger signal transduction pathways resulting in cell death or survival with or without certain amounts of remaining DNA damage (National Aeronautics and Space Administration (USA) [NASA] 2004, Ohnishi et al. 2002). Signal transduction leads to the activation of various transcription factors, resulting in the expression of certain

Correspondence: Dr. med. vet. Christine E. Hellweg, German Aerospace Centre (DLR), Institute of Aerospace Medicine, Radiation Biology, Linder Höhe, D-51147 Köln, Germany. Tel: +492203 601 3243. Fax: +49 220361 970. E-mail: christine.hellweg@dlr.de 
genes whose protein products are involved in several possible outcomes, such as cell cycle arrest, allocating additional time for repair of the damaged DNA, cellular senescence or different types of cell death, if the damage is too severe and cannot be repaired.

An important transcription factor that is known to be activated by ionizing radiation is Nuclear Factor $\kappa \mathrm{B}(\mathrm{NF}-\kappa \mathrm{B})$ (Brach et al. 1991). The NF- $\kappa \mathrm{B} /$ Rel (Reticuloendotheliosis)

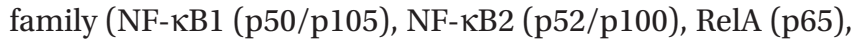
RelB, and c-Rel) can be activated in response to many agents and is involved in regulation of proliferation, immune system development and performance, inflammation and apoptosis (Barnes and Karin 1997, Sonenshein 1997, Wu et al. 1996). Upon activation, the inhibitor of NF- $\kappa \mathrm{B}(\mathrm{I} \kappa \mathrm{B} \alpha)$ that sequesters NF- $\kappa B$ in the cytoplasm (Zabel et al. 1993), is degraded by several proteases (Alkalay et al. 1995) and the released $\mathrm{NF}-\kappa \mathrm{B}$ translocates to the nucleus and binds to $\kappa \mathrm{B}$ DNA motifs (NF- $\kappa \mathrm{B}$ response elements, NRE) initiating gene transcription. NRE have been identified in the promoter or enhancer regions of a number of growth factors, cytokines and adhesion molecules involved in fibrosis and inflammation (Ghosh et al. 1998). In addition, NF- $\kappa B$ regulates the expression of many genes whose products are involved in the control of cell proliferation and cell death (Baichwal and Baeuerle 1997).

Exposure of human cells to energetic heavy ions allows simulation of an important component of the space radiation field, the heavy ion component of galactic cosmic radiation. Currently, experiments are mostly restricted to high-dose rate experiments due to limited beam time availability. Experiments at heavy ion accelerators with various cell lines and primary cells revealed a strong dependency of the relative biological effectiveness (RBE) for the investigated biological endpoint on the LET of the energetic heavy ions and on ion species, energy and charge (for example, Bird and Burki 1975, Stoll et al. 1995, Wulf et al. 1985, Yatagai 2004). For many biological endpoints, e.g., cell inactivation (for example, Blakely et al. 1979), interphase death (Sasaki et al. 1997), differentiation of fibroblasts (Fournier et al. 2001), mutation induction (for example, Cox et al. 1977), in vitro cell transformation (Yang et al. 1985), chromosomal aberrations (Skarsgard et al. 1967) and tumor induction in vivo (Alpen et al. 1993), a maximal RBE was reached with an LET from $90-230 \mathrm{keV} / \mu \mathrm{m}$. The RBE for mutation induction was higher compared to the inactivation RBE for all examined LET values (Yatagai 2004).

There are several hints that the RBE for activation of signaling pathways by heavy ions may also depend on LET and ion species. Screening of gene expression in the nematode Caenorhabditis elegans suggests an LET or track structure dependence of the gene expression changes (Nelson et al. 2002). In human lens epithelial cells, transcription and translation of Cyclin-dependent kinase inhibitor 1A (CDKN1A, Protein 21 Cyclin-dependent kinase 2-interacting protein 1, wild-type p53-activated fragment $1, \mathrm{p} 21^{\mathrm{CIP1} / \mathrm{WAF} 1}$ ) are both temporally regulated after exposure to 4 Gy of high-energy accelerated iron-ion beams $(\sim 150 \mathrm{keV} / \mu \mathrm{m})$ as well as of protons $(\sim 1 \mathrm{keV} / \mu \mathrm{m})$ and $\mathrm{X}$-rays, whereby the magnitude and kinetics of the expression enhancement seem to depend on the LET of the radiation (Chang et al. 2005). Such an LET dependency is also suggested for accumulation of the tumor protein p53 (TP53) (Fournier et al. 2004).

For screening of the cellular NF- $\kappa \mathrm{B}$ response, we developed a recombinant reporter cell line, HEK-pNF- $\kappa \mathrm{B}-\mathrm{d} 2 \mathrm{EGFP} / \mathrm{Neo}$ L2 (Hellweg et al. 2003). These human embryonic kidney (HEK) cells harbor a plasmid which controls the expression of the destabilized variant of enhanced green fluorescent protein (d2EGFP) (Li et al. 1998) as a reporter molecule by a synthetic promoter containing four NRE tandem copies. HEK cells are a useful tool to study many different processes in human cells, as they can easily be transiently and stably transfected. Many studies, including own investigations, have shown that the NF- $\kappa$ B pathway is functional in HEK cells (for example, Matsuda et al. 2003, Hellweg et al. 2006, Muscat et al. 2007, Simon and Samuel 2007, Rajagopal et al. 2008). Additionally, HEK cells express neuronal markers similar to that of neuronal stem cells (Shaw et al. 2002, Arnhold et al. 2008) and are therefore of interest for studying basic mechanisms of space radiation-induced cellular effects. In the recombinant cell system, activation of the cellular NF- $\kappa B$ pathway leads to binding of liberated NF- $\kappa B$ not only to its target genes but also to the synthetic promoter. Thus, the cells respond with increased transcription of d2EGFP, followed by translation and maturation of the protein. By that, it is possible to quantify $\mathrm{NF}-\kappa \mathrm{B}-$ dependent transcriptional activation in response to stimuli simply by measuring the yields of green fluorescence of the reporter protein. In order to overcome problems described for cell-based stable NF- $\kappa \mathrm{B}$ GFP reporter systems (El-Guendy and Sinai 2008), we have shown for the selected clone that the kinetics of activation of NF- $\kappa \mathrm{B}$ dependent d2EGFP gene expression by tumor necrosis factor $\alpha$ (TNF- $\alpha$ ) follows the nuclear translocation of the NF- $\kappa$ B subunit p65 (Hellweg et al. 2003) and that the response to DNA double-strand break inducing agents is intact (Hellweg et al. 2006). The dose-response curve for cytokines and several chemicals (Hellweg et al. 2006) could thus be followed using the HEK-pNF- $\mathrm{BB}-\mathrm{d} 2 \mathrm{EGFP} / \mathrm{Neo}$ cells.

In previous studies, we have shown with this cell system that exposure to accelerated heavy ions (95 MeV/nucleon $[\mathrm{MeV} / \mathrm{n}]$ - Ar, LET $272 \mathrm{keV} / \mu \mathrm{m}$ ) results in stronger activation of NF- $\mathrm{KB}$ in human cells than X-ray exposure (BaumstarkKhan et al. 2005). The NF- $\kappa$ B activation by energetic carbon ions ( 35 and $75 \mathrm{MeV} / \mathrm{n}$, LET 73 and $33 \mathrm{keV} / \mu \mathrm{m}$, respectively) was comparable to the effect induced by X-rays (Hellweg et al. 2011), suggesting a narrow peak in the LET dependence of NF- $\kappa \mathrm{B}$ activation. As this transcription factor is involved in regulation of apoptosis and immune and inflammatory response, its activation may influence the outcome of a heavy ion-exposed cell and therefore might be relevant for late effects which might occur after prolonged low-dose exposure during an interplanetary mission.

In this work, the influence of the LET of several accelerated heavy ions on activation of NF- $\kappa \mathrm{B}$ dependent d2EGFP gene expression and on cellular survival was investigated. Here, we show that radiation qualities, which are relevant for space missions, are capable of activating the NF- $\kappa \mathrm{B}$ pathway and that the activation threshold is in a space flight relevant fluence range for ions in the LET range of 91-272 keV/ $\mu \mathrm{m}$. 


\section{Materials and methods}

\section{Cell culture}

The cell line HEK 293 was established by Graham et al. (1977) from human embryonic kidney cells immortalized by transfection with sheared fragments of adenovirus type 5 DNA. The cells contain only the stably integrated region (E1a and Elb genes) of the human adenovirus genome and do not produce viral particles. Cells were obtained from the American Type Culture Collection (ATCC CRL-1573; now: LGC Standards, Wesel, Germany). Cloning of the plasmid pNF- $\kappa$ B-d2EGFP/ $\mathrm{Neo}$, stable transfection and selection of an appropriate cell

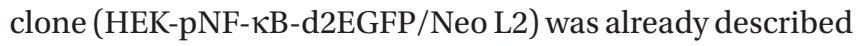
(Hellweg et al. 2003). HEK-pNF-кB-d2EGFP/Neo L2 and untransfected HEK cells have comparable radiosensitivity to $\mathrm{X}$-rays and to accelerated carbon ions and show no difference in proliferation (Hellweg et al. 2011). Cells were maintained in $\alpha$-medium (Biochrom KG, Berlin, Germany)

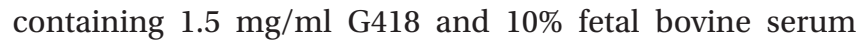
(FBS) at standard conditions $\left(37^{\circ} \mathrm{C}, 95 \%\right.$ air and $5 \% \mathrm{CO}_{2}$ atmosphere). Cells were passaged every week and seeded in a cell density of $3 \times 10^{4}$ cells $/ \mathrm{cm}^{2}$ in $80 \mathrm{~cm}^{2}$ cell culture flasks (Nunc, Novodirect, Kehl, Germany). Medium was exchanged after four days.

\section{Treatment modalities}

For cytokine treatment or irradiation experiments, $3 \times 10^{4}$ cells $/ \mathrm{cm}^{2}$ were seeded into suitable culture vessels freshly coated with poly-D-lysine $\left(10 \mu \mathrm{g} / \mathrm{cm}^{2}\right.$, Sigma-Aldrich Chemie, Steinheim, Germany) for $15 \mathrm{~min}$ followed by washing with phosphate buffered saline (PBS). For exposure to TNF- $\alpha$, $\mathrm{X}$-rays, ${ }^{13} \mathrm{C},{ }^{22} \mathrm{Ne},{ }^{36} \mathrm{Ar}$, and ${ }^{58} \mathrm{Ni}$ ions, cells were seeded into 25 $\mathrm{cm}^{2}$ flasks (Iwaki, Dunn Labortechnik GmbH, Asbach, Germany). For exposure to ${ }^{208} \mathrm{~Pb}$ ions, cells were seeded into Petri dishes with a polytetrafluorethylene bottom (thickness $25 \mu \mathrm{m}$, Lumox, Greiner bio-one, Frickenhausen, Germany), since these ions could not penetrate the polystyrene bottom of standard culture flasks. Cells were incubated for two days before treatment. Control dishes were sham-treated.

\section{Cytokine treatment}

Human recombinant TNF- $\alpha$ was obtained from SigmaAldrich Chemie. TNF- $\alpha$ (final concentration $10 \mathrm{ng} / \mathrm{ml}$ ), was dissolved in PBS, and added in serum-containing medium. Cells were harvested after $18 \mathrm{~h}$ for flow cytometry as described below.

\section{X-irradiation}

Cells in early exponential growth phase were irradiated at room temperature with $150 \mathrm{kV}$ X-rays generated by an X-ray unit (Müller Typ MG 150, Philipps, Hamburg, Germany) yielding a dose rate of $1 \mathrm{~Gy} / \mathrm{min}$.

\section{Heavy ion exposure}

Irradiation with accelerated heavy ions was performed at the Grand Accélérateur National d'Ions Lourds (GANIL, Caen, France). Characteristics of the applied beams including the LET in water are shown in Table I. Adherent cells were irradiated in sub-confluent stage and in upright position at room
Table I. Characteristics of the heavy ion beams.

\begin{tabular}{lcccc}
\hline Ion species & \multicolumn{2}{c}{ Energy $(\mathrm{MeV} / \mathrm{n})^{\mathrm{a}}$} & $\begin{array}{c}\text { LET }(\mathrm{keV} / \mu \mathrm{m}) \\
\text { in } \mathrm{H}_{2} \mathrm{O}\end{array}$ & $\begin{array}{r}\text { Penetration } \\
\text { depth }(\mu \mathrm{m})\end{array}$ \\
\cline { 2 - 4 } beam & on target $^{\mathrm{b}}$ & 71.4 & 34.2 & 15120 \\
Carbon $\left({ }^{13} \mathrm{C}\right)$ & 75.0 & 74.5 & 91.2 & 10000 \\
Neon $\left({ }^{22} \mathrm{Ne}\right)$ & 80.0 & 83.8 & 271.5 & 6336 \\
Argon $\left({ }^{36} \mathrm{Ar}\right)$ & 95.0 & 54.1 & 905.9 & 2092 \\
Nickel $\left({ }^{58} \mathrm{Ni}\right)$ & 75.0 & 19.5 & 9674.0 & 368 \\
Lead $\left({ }^{208} \mathrm{~Pb}\right)$ & 29.2 & &
\end{tabular}

${ }^{\mathrm{a}} \mathrm{MeV} /$ nucleon; ${ }^{\mathrm{b}}$ Effective irradiation energy at the cell monolayer after the energy losses in two detectors, the exit window, $\sim 1 \mathrm{~cm}$ air and the bottom of the culture vessel $(1200 \mu \mathrm{m}$ polystyrene or $25 \mu \mathrm{m}$ polytetrafluoroethylene foil).

temperature. Therefore, flasks and Petri dishes were completely filled with $\alpha$-medium and closed. Petri dishes were wrapped with parafilm. Dose rates were adjusted to $\sim 1 \mathrm{~Gy} / \mathrm{min}$. Dosimetry was performed by the Centre de recherches sur les Ions, les Matériaux et la Photonique (CIMAP) / Laboratoire d'Accueil en Radiobiologie avec les Ions Accélérés (LARIA) staff at GANIL, yielding the fluence in particles $/ \mathrm{cm}^{2}\left(\mathrm{P} / \mathrm{cm}^{2}\right)$. To convert fluence ( $\mathrm{F}$ ) to the absorbed dose, the following formula was applied (Wulf et al. 1985):

$$
\text { Dose }[\mathrm{Gy}]=1.6=10^{-9} \times \operatorname{LET}[\mathrm{keV} / \mu \mathrm{m}] \times \mathrm{F}\left[\mathrm{P} / \mathrm{cm}^{2}\right]
$$

\section{Colony forming ability}

For survival experiments with X-rays and heavy ions, cells were seeded and irradiated as described previously. Immediately after irradiation cells were trypsinized and re-plated in six Petri dishes per dose. The cell density in the dishes was adjusted to compensate for the plating efficiency of the cell line and for the anticipated lethal effect of the radiation in order to allow growth of about 50 colonies per dish.

The cells were incubated for 21 days without medium change. The resulting colonies were stained with crystal violet $(1 \mathrm{mg} / \mathrm{ml}$ in $3 \%$ formaldehyde solution, Sigma-Aldrich Chemie). Only colonies containing more than 50 cells were scored as survivors. The experiments were performed with six dishes per dose and repeated if beam time was available.

All data from the irradiated samples were fit by leastsquares linear regression analysis to $\operatorname{lnS}=\ln \left(\mathrm{PE}_{\mathrm{D}} / \mathrm{PE}_{\mathrm{D}=0}\right)$ versus dose, where the natural logarithm of $S$ is the survival and $\mathrm{PE}$ are the plating efficiencies of treated $\left(\mathrm{PE}_{\mathrm{D}}\right)$ or untreated cells $\left(\mathrm{PE}_{\mathrm{D}=0}\right)$.

\section{Flow cytometry}

For measurement of d2EGFP, cells were harvested $18 \mathrm{~h}$ after radiation or cytokine treatment by trypsinization and fixed with $3 \mathrm{ml}$ cold 3.5\% formaldehyde in PBS. For flow cytometric analysis, cells were centrifuged and resuspended in PBS. Forward and sideward scatter and green fluorescence (FL-1) of 20,000 cells from the samples were measured in a FACScan (Becton Dickinson, San Jose, CA, USA) with an argon laser $(488 \mathrm{~nm})$ as excitation source. The markers d2EGFP ${ }^{(-)}$and $\mathrm{d} 2 \mathrm{EGFP}^{(+)}$were set by means of untreated and TNF- $\alpha$ treated cells (Figure 2A). For comparison of NF- $\kappa \mathrm{B}$-dependent d2EGFP expression after exposure to different radiation qualities, the percentage of $\mathrm{d}_{2} \mathrm{EGFP}^{(+)}$cells in the treated samples was normalized to the percentage of the d2EGFP ${ }^{(+)}$ cells in the corresponding mock-treated controls. 


\section{Calculation of relative biological effectiveness}

The relative biological effectiveness (RBE) was calculated according to the formula:

$\mathrm{RBE}=\frac{\text { Absorbed dose of reference radiation inducing biological effect }[\mathrm{Gy}]}{\text { Absorbed dose of test radiation inducing biological effect [Gy] }}$

Fluences were converted to energy dose according to Equation (1). The reference radiation was $150 \mathrm{kV}$ X-rays.

\section{Survival}

The $\mathrm{D}_{0}$, the reciprocal of the slope in the linear range of the survival curves, was used for RBE calculation. The $\mathrm{D}_{0}$ was converted to absorbed dose for heavy ion exposure. The RBE for survival was calculated as follows:

$$
\mathrm{RBE}_{\text {Survival }}=\frac{\mathrm{D}_{0} \text { reference radiation }[\mathrm{Gy}]}{\mathrm{D}_{0} \text { energetic heavy ion }[\mathrm{Gy}]}
$$

\section{Activation of NF- $\kappa$ B dependent d2EGFP gene expression}

Using Sigma Plot 2002 for Windows Version 8.02 (Systat Software $\mathrm{GmbH}$, Erkrath, Germany), a regression was adapted to each dose effect curve of NF- $\kappa \mathrm{B}$ dependent d2EGFP gene expression activation, based on the regression coefficient. The doses initiating a doubling of the d2EGFP fluorescence in HEK-pNF- $\kappa B$-d2EGFP/Neo L2 cells $18 \mathrm{~h}$ after irradiation were derived from the regression curves. These doses were used as indicator of the threshold for activation of NF- $\kappa B$ dependent d2EGFP gene expression. The RBE for NF- $\kappa B$ dependent d2EGFP gene expression was calculated by dividing according to formula (2) the absorbed dose [Gy] of the reference radiation that elicited a doubling of d2EGFP fluorescence $18 \mathrm{~h}$ after irradiation by the absorbed dose [Gy] of energetic heavy ions inducing the same biological effect.

\section{Statistics}

Each experiment was repeated up to five times depending on the availability of beam time with one to six replicates each. Beam time is very restricted and it was not possible to repeat the experiments in independent beam times for every ion analyzed in this work. In order to account for different numbers of replicates and repeats, the standard error was calculated. Means, standard errors and significance levels in the t test were calculated with Microsoft ${ }^{\circledR}$ Office Excel 2003 (Microsoft Deutschland GmbH, München, Germany). The $t$-test can be used even with small sample sizes. Regression analyses were performed using SigmaPlot 2002.

\section{Results}

The effect of different energetic heavy ions on the NF- $\kappa$ B pathway was studied in human embryonic cells. Heavy ion fluences resulting in absorbed doses between 0.2 and $60 \mathrm{~Gy}$, depending on the anticipated killing effect of the examined ion (Stoll et al. 1995), were selected for the experiments.

\section{Survival of human embryonic cells after X-ray and after heavy ion exposure}

There are no significant differences in the survival of untransfected HEK cells and stably transfected
HEK-pNF- $\kappa$ B-d2EGFP/Neo clone L2 cells after X-irradiation and after carbon ion exposure (Hellweg et al. 2011).

High-LET radiation exposure of HEK cells results in purely exponential survival curves (Figure 1A). Based on fluence, the cell killing potential strongly increases with LET up to $272 \mathrm{keV} / \mu \mathrm{m}$. The increase of the killing effect from 272-9674 $\mathrm{keV} / \mu \mathrm{m}$ is less prominent. Based on absorbed dose, heavy ions with an LET of 34-91 keV/ $\mu \mathrm{m}$ are most efficient in cell killing, while radiation qualities with an LET above or below this range are less efficient in cell killing (Figure 1B). Lead ions with an extremely high LET are least efficient in reducing cellular survival. Exposure to X-rays resulted in a slightly shouldered survival curve (Figure 1B).
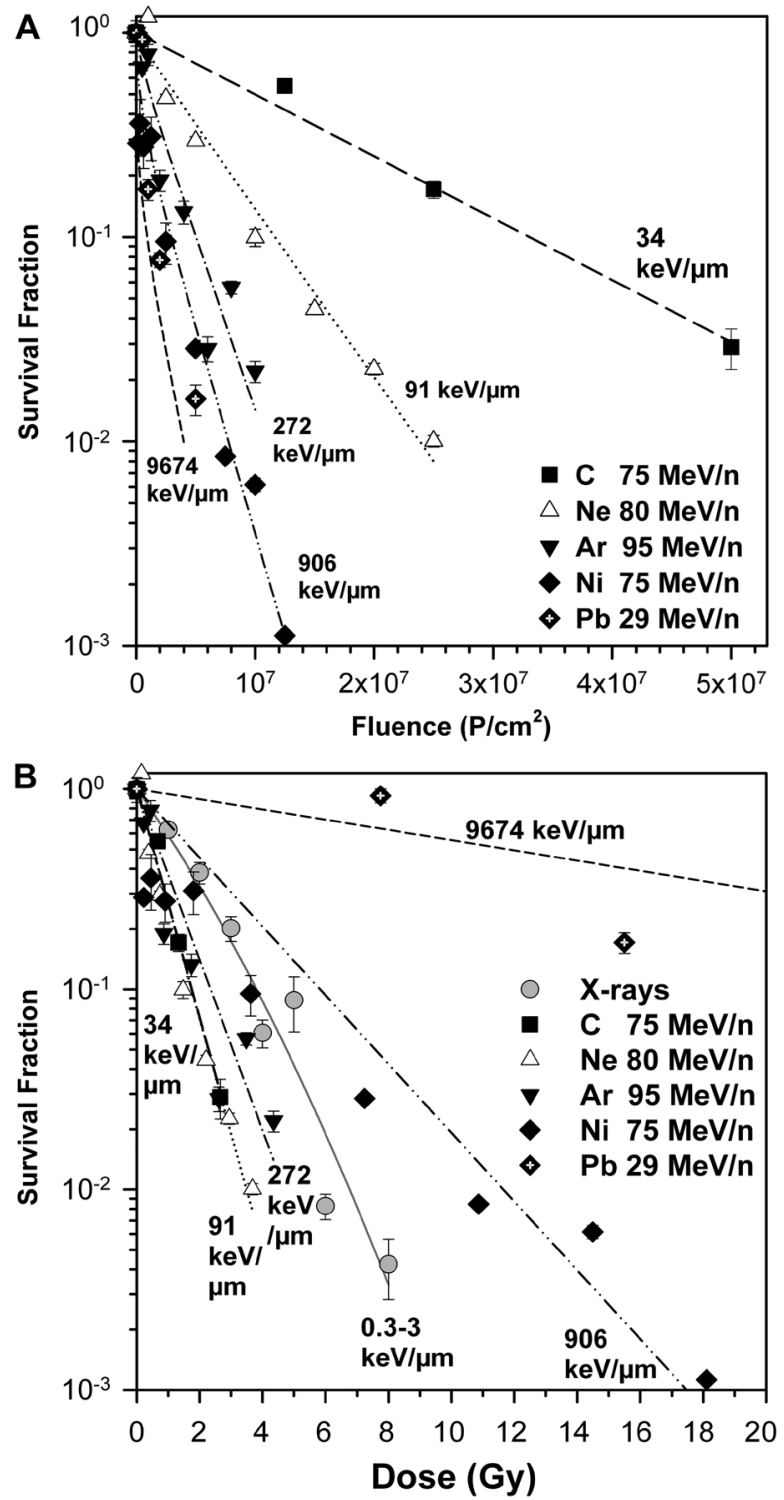

Figure 1. Clonogenic survival after exposure of HEK-pNF- $\mathrm{BB}-\mathrm{d} 2 \mathrm{EGFP} /$ Neo cells to X-rays or to heavy ions, as fluence-effect curves (A) and dose-effect curves (B). HEK-pNF- $\kappa \mathrm{B}-\mathrm{d} 2 \mathrm{EGFP} / \mathrm{Neo}$ cells were exposed to $150 \mathrm{kV}$ X-rays or to accelerated carbon, neon, argon, nickel or lead ions (A, B). Survival was determined by the colony forming ability test (CFA). Irradiated cells were seeded in Petri dishes. Grown colonies were fixed and stained after 14-21 days incubation. Data of one to five experiments were combined (X-rays: $5 ;{ }^{36} \mathrm{Ar}: 3 ;{ }^{13} \mathrm{C},{ }^{58} \mathrm{Ni},{ }^{208} \mathrm{~Pb}: 2 ;{ }^{22} \mathrm{Ne}: 1$ ); bars show standard error of up to 30 Petri dishes (5-6 per dose per independent experiment). $\mathrm{P} / \mathrm{cm}^{2}=$ particles $/ \mathrm{cm}^{2}, \mathrm{MeV} / \mathrm{n}=\mathrm{MeV} /$ nucleon. 
The $\mathrm{D}_{0}$ indicating the fluence necessary to reduce survival of HEK cells to $37 \%$ first decreases, then increases with increasing LET. The $\mathrm{D}_{0}$ ranges between $2.5 \times 10^{7} \mathrm{P} / \mathrm{cm}^{2}(1.4$ Gy) for ${ }^{13} \mathrm{C}$ ions $(75 \mathrm{MeV} / \mathrm{n}), \sim 2.2 \times 10^{6} \mathrm{P} / \mathrm{cm}^{2}$ (3.1 Gy) for nickel ions and $1.2 \times 10^{6} \mathrm{P} / \mathrm{cm}^{2}(18.2 \mathrm{~Gy})$ for lead ions. These fluences result in average in 35.5, 3.1 and 1.5 hits per cell nucleus, respectively.

\section{Induction of NF- $\kappa$ B dependent d2EGFP gene expression by exposure to different radiation qualities}

Previous experiments with TNF- $\alpha$ and argon ions revealed that the maximal d2EGFP fluorescence (3-6 $\mathrm{h}$ are necessary for d2EGFP translation, transcription and maturation) occurs $12-24 \mathrm{~h}$ after treatment (Hellweg et al. 2003, 2005, Baumstark-Khan et al. 2005). Therefore, $18 \mathrm{~h}$ was chosen as intermediate time point. HEK-pNF- $\kappa$ B-d2EGFP/Neo cells responded to TNF- $\alpha$ $(10 \mathrm{ng} / \mathrm{ml})$ with a strong increase of d2EGFP fluorescence $(\sim 60 \%$ positive cells at $18 \mathrm{~h}$, Figure $2 \mathrm{~A}$ ).

As argon ions strongly activate the NF- $\kappa B$ pathway (see below), fluorescence histograms of d2EGFP expression are shown in detail for this ion. After exposure with $95 \mathrm{MeV} / \mathrm{n}$ argon ions (Figure 2B), an increase in d2EGFP fluorescence is observed already after exposure to the lowest fluence. Part of the cell population shows a very strong fluorescence increase, and this subpopulation increases dose-dependently. The rest of the population shows only a small increase in fluorescence which is slightly dose-dependent.

Radiation experiments using low-LET ionizing radiation (150 kV X-rays) and moderate LET $\left(75 \mathrm{MeV} / \mathrm{n}^{13} \mathrm{C}\right.$ ions) show a dose-dependent increase of NF- $\mathrm{\kappa B}$ dependent d2EGFP fluorescence (Figure 3A).

The comparison of the activation of NF- $\mathrm{KB}$ dependent d2EGFP gene expression by radiation of different LET reveals the maximal potency for neon and argon ions (Figure 3B). In average, 2.4 argon ion hits per cell nucleus ( $0.7 \mathrm{~Gy}$ ) result in doubling of NF- $\mathrm{KB}$ dependent d2EGFP gene expression. For nickel and lead ions, a significant increase of fluorescence occurs at doses above 3.6 Gy and 10.6 Gy, respectively (Figure $3 \mathrm{C}$ ). Nickel ions activate NF- $\kappa B$ dependent d2EGFP expression to an extent comparable to X-rays, and lead ions have a lower activating potency than X-rays (Figure 3C). Much higher fluences are required for maximal induction of NF- $\mathrm{KB}$ dependent d2EGFP gene expression in HEK cells. Depending on the radiation quality, the maximal activation is provoked by energy doses above $10 \mathrm{~Gy}$ (carbon, neon, argon), above 15 Gy (nickel, X-rays) or above 60 Gy (lead). After argon ion exposure, the number of d2EGFP ${ }^{(+)}$cells decreases after reaching the maximum (Figure 3B), while after neon, nickel and lead ion exposure, the maximum is not reached in the examined dose range (Figure 3B, 3C).

\section{Relative biological effectiveness of different energetic heavy ions}

The RBE for survival was calculated from the $\mathrm{D}_{0}$. For NF- $\mathrm{\kappa B}$ activation, the dose in Gy exposure to which resulted in doubling of the d2EGFP fluorescence was chosen for RBE calculation, as not all curves reached a clear maximum, precluding the determination of the dose that initiated maximal response. The maximal biological effect was observed
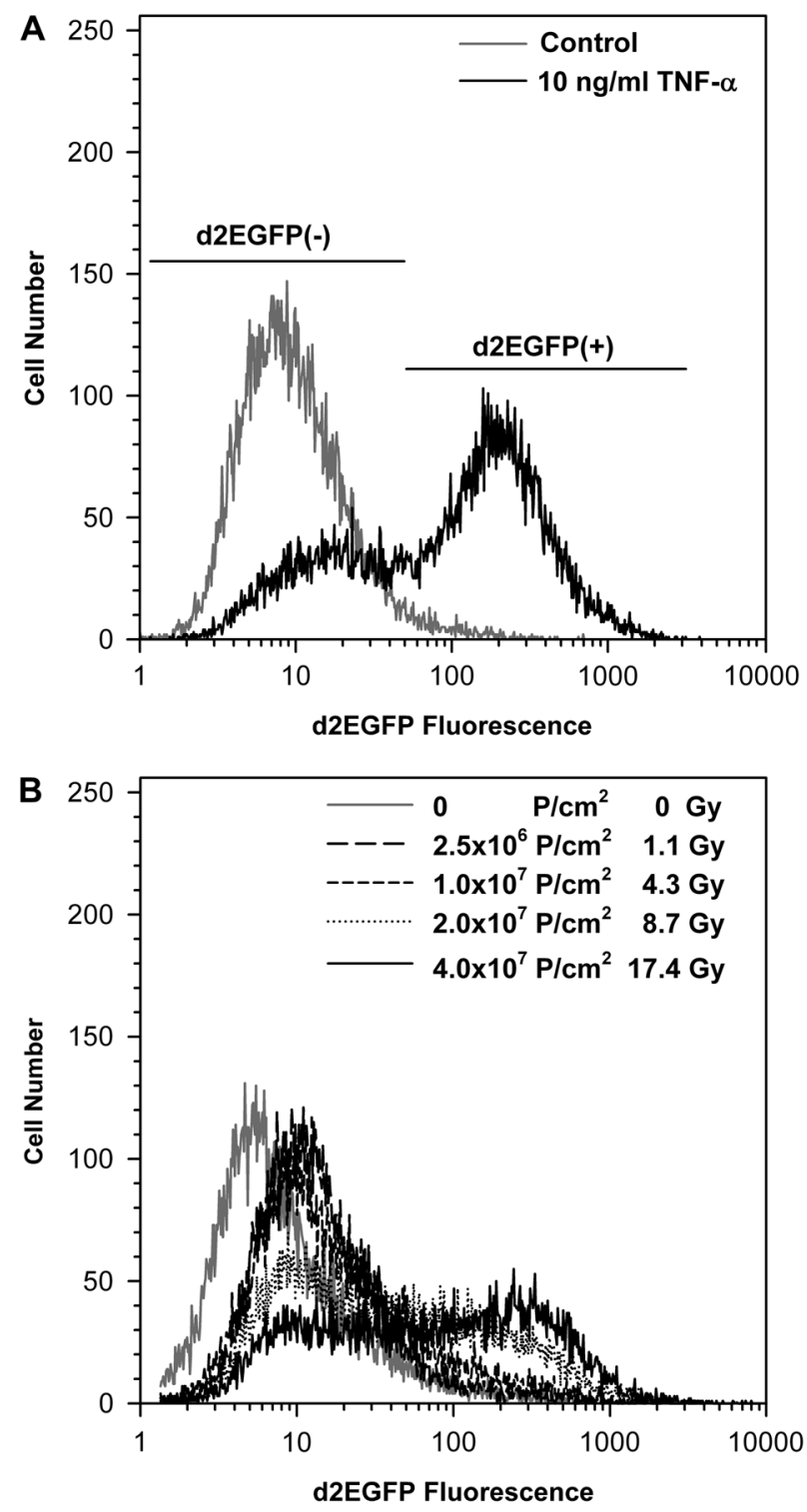

Figure 2. Activation of NF- $\mathrm{kB}$-dependent d2EGFP gene expression by tumor necrosis factor $\alpha$ (TNF- $\alpha)$ and by high LET radiation, as detected in stably transfected HEK cells from d2EGFP reporter gene expression controlled by a promoter containing four NRE and the minimal promoter of thymidine kinase (TK) (HEK-pNF- $\mathrm{KB}-\mathrm{d} 2 \mathrm{EGFP} /$ Neo clone L2). Cells were harvested and fixed for flow cytometry $18 \mathrm{~h}$ after treatment. Histogram overlays of representative flow cytometric analyses are shown in A and B. As positive control for activation of NF- $\kappa B$ dependent d2EGFP gene expression, cells were treated with 10 $\mathrm{ng} / \mathrm{ml}$ TNF- $\alpha$ (A). An overlay of d2EGFP fluorescence histograms of cells exposed to ${ }^{36} \mathrm{Ar}$ ions ( $95 \mathrm{MeV} / \mathrm{n}$, LET $272 \mathrm{keV} / \mu \mathrm{m}$ ) is shown in $\mathrm{B}$. Fluences were converted to absorbed doses according to Equation (1). $\mathrm{P} / \mathrm{cm}^{2}=$ particles $/ \mathrm{cm}^{2}$.

between 91 und $272 \mathrm{keV} / \mu \mathrm{m}$ for the examined endpoints survival and activation of NF- $\mathrm{KB}$ dependent d2EGFP gene expression (Figure 4). The extent of the RBE strongly depends on the nature of effect. The highest relative biological effectiveness for induction of NF- $\mathrm{\kappa B}$ dependent d2EGFP gene expression is 8.9 (Figure $4 \mathrm{~B}$ ), for reproductive cell death only around 2 (Figure $4 \mathrm{~A})$.

\section{Discussion}

In this study, we show that energetic argon ions (LET 272 $\mathrm{keV} / \mu \mathrm{m}$ ) and neon ions (LET $91 \mathrm{keV} / \mu \mathrm{m}$ ) are most effective 

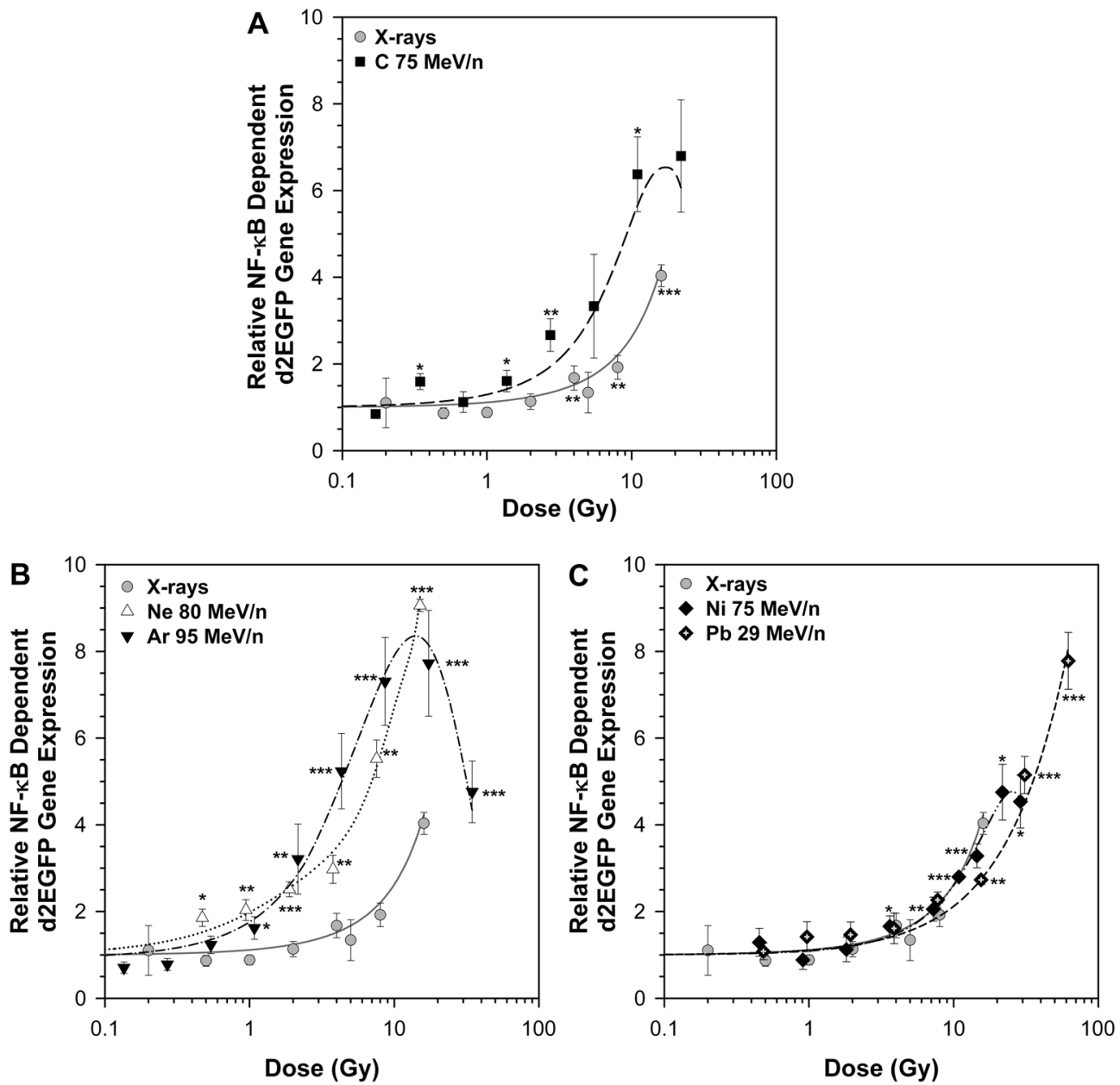

Figure 3. Dose effect relationships for activation of NF- $\mathrm{KB}$-dependent d2EGFP gene expression after exposure to X-rays or to various energetic heavy ions, as detected in stably transfected HEK cells by the reporter gene d2EGFP controlled by the promoter containing four NRE and the minimal

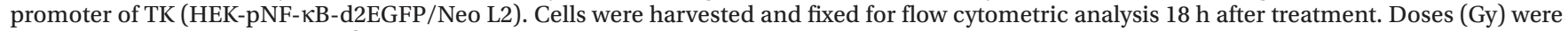
calculated from fluences $\left(\mathrm{P} / \mathrm{cm}^{2}\right)$ according to Equation (1). Means and standard deviations of one to five independent experiments (X-rays: 5 ; ${ }^{36} \mathrm{Ar}: 4 ;{ }^{13} \mathrm{C},{ }^{58} \mathrm{Ni}: 2 ;{ }^{22} \mathrm{Ne},{ }^{208} \mathrm{~Pb}$ : 1) with 3-6 samples per dose are shown. Significance compared to the mock-irradiated control: ${ }^{*} p<0.05$, ${ }^{* *} p<0.01$, ${ }^{* * *} p<0.001$ (for X-rays only shown in A). $\mathrm{MeV} / \mathrm{n}=\mathrm{MeV} /$ nucleon.

in activating NF- $\mathrm{KB}$ dependent d2EGFP gene expression in human embryonic kidney cells. Relative biological effectiveness for survival reduction also peaks in this LET range, but the RBE is much lower.

\section{Clonogenic survival}

The survival curves' exponential course without shoulder after heavy ion exposure conforms to previously published data for the survival of human mammary epithelial cells (Durante et al. 1995), human kidney cells (T-1) (Yang et al. 1977), melanoma and Chinese Hamster Ovary (CHO) cells (Bird and Burki 1975) and CHO V79 cells (Stoll et al. 1995). The analysis of cell death of glioblastoma cell lines after exposure to high LET carbon beams by the colony forming ability test revealed an LET dependent decrease in survival fraction (Tsuchida et al. 1998). Such an LET dependence of reproductive cell death was also observed in human fibroblasts (Hamada et al. 2006). Also in this work, the fluences necessary for cell inactivation were dependent on the LET of the examined heavy ion beams. The higher the LET, the lower were the fluences to achieve the same killing effect. Based on dose, the relationship is more complex, with a maximal killing effect in the range of $34-91 \mathrm{keV} / \mu \mathrm{m}$, as the fluences are weighted with the respective LET for conversion to absorbed dose according to Equation (1).

\section{Activation of the NF- $\kappa B$ pathway by different energetic heavy ions}

Our first study examining the effects of heavy ions on the NF- $\kappa B$ pathway revealed that high LET argon ions $(272 \mathrm{keV} / \mu \mathrm{m})$ activate the sequence of all events in the NF- $\kappa B$ pathway from DNA binding via transcription to protein translation and maturation (Baumstark-Khan et al. 2005). Here, the LET dependence of this cellular response to heavy ion exposure was examined. Argon ions $(272 \mathrm{keV} / \mu \mathrm{m})$ have the maximal potency to activate NF- $\kappa \mathrm{B}$ dependent d2EGFP gene expression in HEK cells. Neon ions $(91 \mathrm{keV} / \mu \mathrm{m})$ have a strong potency for NF- $\mathrm{\kappa B}$ activation, and the maximal response was not reached in the examined dose range.

In line with the results presented here, other groups report NF- $\kappa \mathrm{B}$ translocation after exposure of normal human monocytes (MM6 cells) to $0.7 \mathrm{~Gy}$ of ${ }^{56} \mathrm{Fe}$ ions using a DNA binding assay (Natarajan et al. 2002). This clearly indicates that high LET iron ion exposure induces rapid and persistent NF- $\kappa B$ 

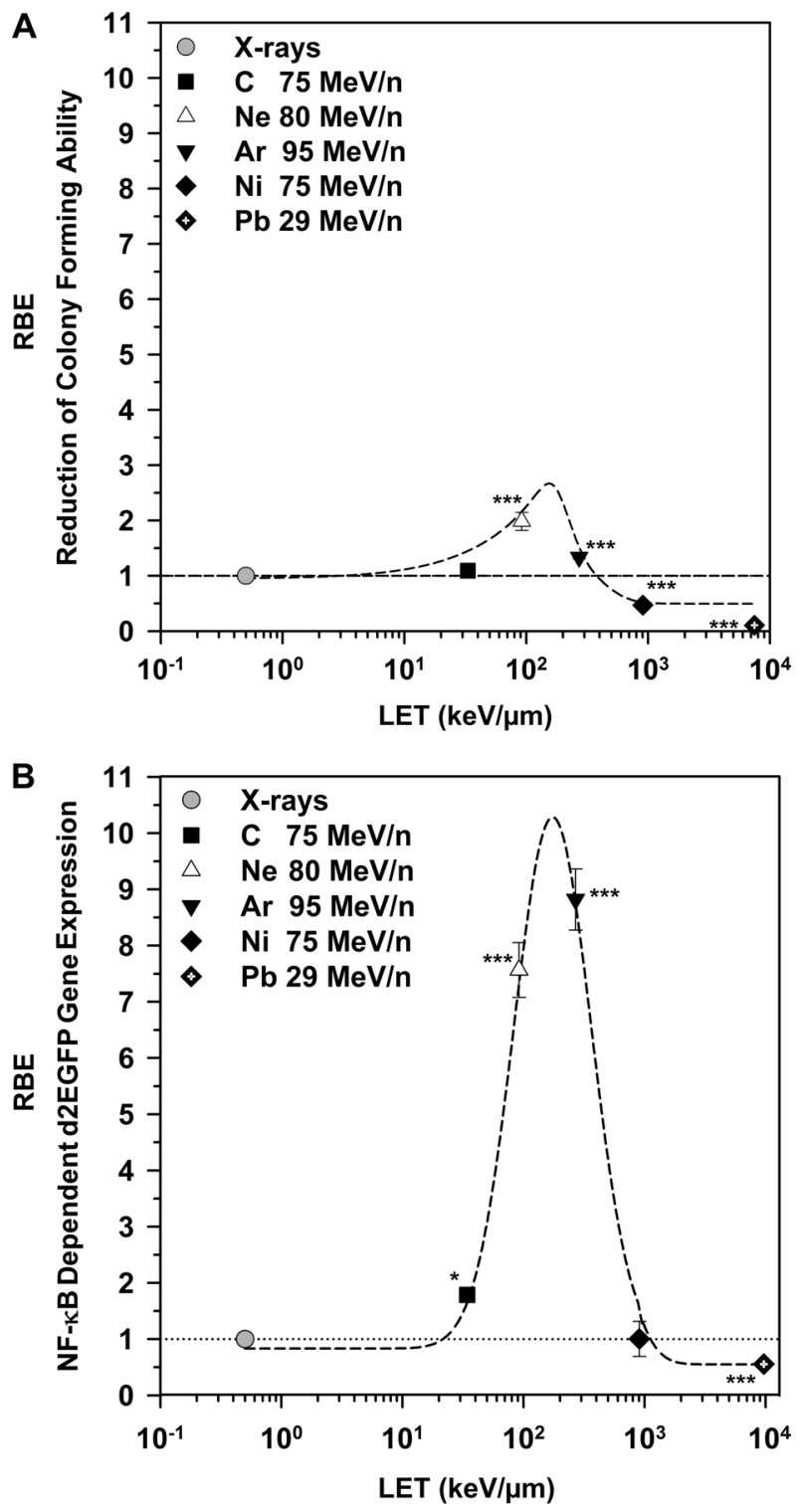

Figure 4. Relative Biological Effectiveness (RBE) of energetic ions of different LET in inducing reproductive cell death (A), as measured by colony forming ability, and in activating NF- $\kappa B$ dependent d2EGFP gene expression (B). $150 \mathrm{kV} \mathrm{X-rays} \mathrm{were} \mathrm{used} \mathrm{as} \mathrm{reference} \mathrm{radiation} \mathrm{and} \mathrm{RBE}$ was calculated according to Equation (2). The $D_{0}$ as descriptor of the survival curves was converted to energy dose for heavy ion exposure (A). The fluences eliciting a doubling of the NF- $\mathrm{KB}$-dependent fluorescence signal were converted to absorbed dose (B). Means and standard errors for one to five beam times per radiation quality with six replicates are shown (Number of beam times: X-rays: $5 ;{ }^{36} \mathrm{Ar}: 4,{ }^{13} \mathrm{C},{ }^{58} \mathrm{Ni},{ }^{208} \mathrm{~Pb}: 2 ;{ }^{22} \mathrm{Ne}$ : 1). "Significant difference to the $\mathrm{X}$-ray induced cellular response with $p<0.05$, ** with $p<0.01$, or ${ }^{* * *}$ with $p<0.001 . \mathrm{MeV} / \mathrm{n}=\mathrm{MeV} /$ nucleon.

activation. This activation of NF- $\kappa \mathrm{B}$ was shown to be mediated through phosphorylation of $\operatorname{I\kappa B} \alpha$ and the subsequent proteasome-dependent degradation pathway. The iron study only revealed binding of NF- $\kappa B$ to its consensus sequence of 5'-GGGGACTTTCC-3', and not transcriptional activation. Mitra et al. $(2004,2005)$ determined that the expression of the transcription factor NF- $\kappa \mathrm{B}$ itself is influenced by ${ }^{16} \mathrm{O}$ and ${ }^{12} \mathrm{C}$ ion exposure (LET not published) in $\mathrm{CHO}$ V79 cells. Exposure to ${ }^{16} \mathrm{O}$ ions first decreased p65 expression as detected by Western blot 0.5 and $2 \mathrm{~h}$ after irradiation, with a recovery slightly over the initial cellular p65 content $4 \mathrm{~h}$ after irradiation (Mitra et al. 2004). NF- $\kappa B$ p65 expression was enhanced by ${ }^{12} \mathrm{C}$ ion exposure $8 \mathrm{~h}$ after $0.1 \mathrm{~Gy}$ and already $3 \mathrm{~h}$ after 1 Gy (Mitra et al. 2005). Together with the half-life of the reporter protein $\mathrm{d} 2 \mathrm{EGFP}$, this enhanced NF- $\mathrm{KB}$ availability might explain the sustained NF- $\kappa \mathrm{B}$ dependent $\mathrm{d} 2 \mathrm{EGFP}$ gene expression which was observed $18 \mathrm{~h}$ after heavy ion exposure. Up-regulation of NF- $\kappa \mathrm{B}$ activating cytokines such as interleukins and tumor necrosis factor might also play a role in perpetuating the NF- $\kappa \mathrm{B}$ activation. The DNA-dependent protein kinase (DNA-PK) and phosphatidyl inositol kinase 3 (PI3 kinase) inhibitor Wortmannin $(10 \mu \mathrm{mol} / \mathrm{l})$ enhanced the ${ }^{12} \mathrm{C}$ ion-induced expression of NF- $\kappa \mathrm{B}$ (Mitra et al. 2005). In oral squamous cell carcinoma cells, a microarray analysis after carbon and neon ion (LET $\sim 75 \mathrm{keV} / \mu \mathrm{m} ; 1,4,7 \mathrm{~Gy}$ ) irradiation revealed no significant gene expression changes in the NF- $\kappa \mathrm{B}$ signaling pathway (Fushimi et al. 2008). Whether the lack of inducible NF- $\kappa \mathrm{B}$ activation is specific for these cancer cells, e.g., because of a constitutively highly active NF- $\kappa B$ pathway (Nakayama et al. 2001, Tamatani et al. 2001, Bindhu et al. 2006), or if methodological differences are responsible for the contrary results, it remains to be determined.

The appearance of two populations in the d2EGFP histogram after argon ion exposure might be explained by two different processes: The population with the strong fluorescence increase shows high d2EGFP expression in response to binding of liberated NF- $\kappa \mathrm{B}$ to the synthetic promoter of the stably transfected reporter construct. The subpopulation showing only a very small shift towards higher fluorescence intensities might result from radiation-induced cell cycle arrest, during which d2EGFP continues to accumulate without 'dilution' by cell division. Such a shift was described for UVC-irradiated stably transfected Chinese Hamster Ovary Cells that constitutively expressed EGFP (Baumstark-Khan et al. 1999). The threshold for the d2EGFP ${ }^{(+)}$cells was set above this subpopulation, in order to exclude possibly unspecific d2EGFP fluorescence.

As activation of the NF- $\kappa \mathrm{B}$ pathway is supposed to play a role in the negative regulation of apoptosis, survival of cells with residual DNA damage might thus be favored. Even if this happens only in a small fraction of irradiated cells, it might be important for the initiation or promotion of cancer. Such effects which may be related to better survival of exposed cells through transitory induction of genes involved in maintaining DNA fidelity and in modulating cell-cycle progression and cell-death, would contribute considerably to astronauts' radiation risk, especially at low doses (Williams et al. 1999).

Enhanced expression of cytokines and extracellular matrix proteases which are regulated by NF- $\kappa \mathrm{B}$ after heavy ion exposure might also contribute to the remodeling of extracellular matrix that is observed after particle irradiation (NCRP 2006). Activation of NF- $\kappa \mathrm{B}$ by high radiation doses (1-10 Gy) could contribute to the inflammatory response observed, e.g., in the developing brain after radiation exposure (Monje et al. 2003).

\section{Relative biological effectiveness of different energetic heavy ions}

In this work, the maximal biological effect for the two examined endpoints peaks between 91 and $272 \mathrm{keV} / \mu \mathrm{m}$. As mentioned 
in the Introduction, other groups locate maximal biological effectiveness of energetic heavy ions in the range of 90-230 keV/ $\mu \mathrm{m}$.

The maximal relative biological effectiveness strongly depends on the nature of the effect and the cell type. As found in this work, the RBE for activation of NF- $\kappa \mathrm{B}$ dependent d2EGFP gene expression is around 9, for reproductive cell death only around 2 . The RBE for reproductive cell death is very similar to the RBE for DNA double-strand break induction $(\sim 1.8)$ by energetic heavy ions (Löbrich et al. 1996, Whalen et al. 2008). The RBE for survival also depends on the survival level used for its calculation, and its maximum was described to range between 2 and 4 (Blakely et al. 1984, Alpen et al. 1993, Tsuruoka et al. 2005, Hamada et al. 2006). For LET values above $900 \mathrm{keV} / \mu \mathrm{m}$, RBE values for reproductive cell death drop below 1, which is in line with observations by Tolkendorf and Eichhorn (1983), Wulf et al. (1985) and Fournier et al. (2001). This overkill effect is explained by an increase in the degree of clustering of the initial physical damage within the target area with an increasing LET. It is seen as cause for the appearance of non-hit cells and the decrease in the mean number of lethal damage per unit dose, resulting in the decrease of RBE for cell killing (Mehnati et al. 2005).

Assuming that NF- $\kappa \mathrm{B}$ activation promotes survival, it can be hypothesized that the extreme capacity of energetic heavy ions in the LET range of $90-300 \mathrm{keV} / \mu \mathrm{m}$ to activate NF- $\kappa \mathrm{B}$ 's transcriptional effects might be responsible for the lower relative effectiveness in cell killing observed in this range. Above $300 \mathrm{keV} / \mu \mathrm{m}$ the overkill effect possibly results in a decrease of the relative biological effectiveness.

Under these aspects, one can ask how can activated NF- $\kappa \mathrm{B}$ influence the survival of heavy ion-irradiated cells? Possible pro-survival genes that might be transcribed at a higher rate are the inhibitor of apoptosis protein genes (IAP), and other anti-apoptotic genes such as bcl-2 (B-cell lymphoma 2), bcl-XL (B-cell lymphoma-extra large) and survivin. Preliminary experiments by Gong et al. have shown that high-LET radiation has a higher potential to activate survivin expression compared to low-LET radiation (Gong et al. 2007, Jin et al. 2008).

The small numbers of particle tracks per cell nucleus - in the narrow LET range where the RBE reaches its maximum which are necessary to activate NF- $\kappa \mathrm{B}$ suggest that NF- $\kappa \mathrm{B}$ activation might be relevant for judging the biological effects of heavy ion exposures during long-term space missions. Availability of more sensitive methods to screen NF- $\kappa B$ activation in large sample numbers might enlarge this LET range.

The LET dependence of NF- $\kappa \mathrm{B}$ activation found in this work might suggest that a differential activation of cellular signaling pathways by different radiation qualities could contribute to the underlying causes of the LET dependency of biological endpoints such as cell inactivation and mutation or chromosomal aberration induction.

\section{Acknowledgements}

We thank Dr Hermann Rothard and all the physicists of CIMAP (Caen, France) involved in dosimetry and the beam operator team at GANIL for providing us valuable advice and many help given during numerous night shifts at the French Heavy Ion Accelerator GANIL. The travel costs to the GANIL were supported in part by the European Union (EURONS). Luis Spitta, Melanie Thelen, Dimitri Ott, Britta Langen, Rebecca Ruland, Kristina Koch, Yueyuan Hu, Arif Ali Chishti and Sebastian Feles are acknowledged for their valuable help during beam times at GANIL.

\section{Declaration of interest}

The authors report no conflicts of interest. The authors alone are responsible for the content and writing of the paper.

\section{References}

Alkalay I, Yaron A, Hatzubai A, Orian A, Ciechanover A, Ben-Neriah Y. 1995. Stimulation-dependent I kappa B alpha phosphorylation marks the NF-kappa B inhibitor for degradation via the ubiquitin-proteasome pathway. Proceedings of the National Academy of Sciences of the USA 92:10599-10603.

Alpen EL, Powers-Risius P, Curtis SB, DeGuzman R. 1993. Tumorigenic potential of high-Z, high-LET charged-particle radiations. Radiation Research 136:382-391.

Arnhold S, Post C, Gluer S, Hoopmann M, Wenisch S, Volpers C, Addicks K. 2008. Neuronal characteristics of amniotic fluid derived cells after adenoviral transformation. Cell Biology International 32:1559-1566.

Baichwal VR, Baeuerle PA. 1997. Activate NF-kappa B or die? Current Biology 7:R94-96.

Barnes PJ, Karin M. 1997. Nuclear factor-kappaB: A pivotal transcription factor in chronic inflammatory diseases. New England Journal of Medicine 336:1066-1071.

Baumstark-Khan C, Hellweg CE, Arenz A, Meier MM. 2005. Cellular monitoring of the nuclear factor kappaB pathway for assessment of space environmental radiation. Radiation Research 164:527-530.

Baumstark-Khan C, Palm M, Wehner J, Okabe M, Ikawa M, Horneck G. 1999. Green Fluorescent Protein (GFP) as a marker for cell viability after UV irradiation. Journal of Fluorescence 9:37-43.

Bindhu OS, Ramadas K, Sebastian P, Pillai MR. 2006. High expression levels of nuclear factor kappa $\mathrm{B}$ and gelatinases in the tumorigenesis of oral squamous cell carcinoma. Head \& Neck 28:916-925.

Bird RP, Burki HJ. 1975. Survival of synchronized Chinese hamster cells exposed to radiation of different linear-energy transfer. International Journal of Radiation Biology \& Related Studies in Physics, Chemistry \& Medicine 27:105-120.

Blakely EA. 2000. Biological effects of cosmic radiation: Deterministic and stochastic. Health Physics 79:495-506.

Blakely EA, Ngo FQH, Curtis SB, Tobias CA. 1984. Heavy-ion radiobiology: Cellular studies. Advances in Radiation Biology 11:295-389.

Blakely EA, Tobias CA, Yang TC, Smith KC, Lyman JT. 1979. Inactivation of human kidney cells by high-energy monoenergetic heavy-ion beams. Radiation Research 80:122-160.

Brach MA, Hass R, Sherman ML, Gunji H, Weichselbaum RR, Kufe DW. 1991. Ionizing radiation induces expression and binding activity of the nuclear factor kappa B. Journal of Clinical Investigation 88:691-695.

Chang PY, Bjornstad KA, Rosen CJ, McNamara MP, Mancini R, Goldstein LE, Chylack LT, Blakely EA. 2005. Effects of iron ions, protons and $\mathrm{X}$ rays on human lens cell differentiation. Radiation Research 164:531-539.

Cox R, Thacker J, Goodhead DT, Munson RJ. 1977. Mutation and inactivation of mammalian cells by various ionising radiations. Nature 267: 425-427.

Cucinotta FA, Kim MHY, Ren L. 2005. Managing lunar and Mars mission radiation risks. Part 1: Cancer risks, uncertainties, and shielding effectiveness. NASA/TP-2005-21364. 2005. Hanover, MD: Center for Aerospace Information.

Durante M, Grossi GF, Gialanella G, Pugliese M, Nappo M, Yang TC. 1995. Effects of alpha-particles on survival and chromosomal aberrations in human mammary epithelial cells. Radiation and Environmental Biophysics 34:195-204.

El-Guendy N, Sinai AP. 2008. Potential problems inherent in cell-based stable NF-kappaB-GFP reporter systems. Molecular and Cellular Biochemistry 312:147-155. 
Fournier C, Scholz M, Weyrather WK, Rodemann HP, Kraft G. 2001. Changes of fibrosis-related parameters after high- and low-LET irradiation of fibroblasts. International Journal of Radiation Biology 77:713-722.

Fournier C, Wiese C, Taucher-Scholz G. 2004. Accumulation of the cell cycle regulators TP53 and CDKN1A (p21) in human fibroblasts after exposure to low- and high-LET radiation. Radiation Research 161:675-684.

Fushimi K, Uzawa K, Ishigami T, Yamamoto N, Kawata T, Shibahara T, Ito H, Mizoe JE, Tsujii H, Tanzawa H. 2008. Susceptible genes and molecular pathways related to heavy ion irradiation in oral squamous cell carcinoma cells. Radiotherapy Oncology 89:237-244.

Ghosh S, May MJ, Kopp EB. 1998. NF-kappa B and Rel proteins: Evolutionarily conserved mediators of immune responses. Annual Review of Immunology 16:225-260.

Gong L, Jin X, Li Q, Liu J, An L. 2007. Heavy ion beams induce survivin expression in human hepatoma SMMC-7721 cells more effectively than X-rays. Acta Biochimica et Biophysica Sinica (Shanghai) 39: 575-582.

Graham FL, Smiley J, Russell WC, Nairn R. 1977. Characteristics of a human cell line transformed by DNA from human adenovirus type 5. Journal of General Virology 36:59-74.

Hamada N, Funayama T, Wada S, Sakashita T, Kakizaki T, Ni M, Kobayashi Y. 2006. LET-dependent survival of irradiated normal human fibroblasts and their descendents. Radiation Research 166:24-30.

Hellweg CE, Arenz A, Bogner S, Schmitz C, Baumstark-Khan C. 2006. Activation of nuclear factor kappa B by different agents: Influence of culture conditions in a cell-based assay. Annals of the New York Academy of Sciences 1091:191-204.

Hellweg CE, Baumstark-Khan C. 2007. Getting ready for the manned mission to Mars: The astronauts' risk from space radiation. Naturwissenschaften 94:517-526.

Hellweg CE, Baumstark-Khan C, Horneck G. 2003. Generation of stably transfected mammalian cell lines as fluorescent screening assay for NF-kappaB activation-dependent gene expression. Journal of Biomolecular Screening 8:511-521.

Hellweg CE, Baumstark-Khan C, Schmitz C, Lau P, Meier MM, Testard I, Berger T, Reitz G. 2011. Carbon ion induced activation of the NFkappaB pathway. Radiation Research 175:424-431.

Hellweg CE, Arenz A, Meier MM, Baumstark-Khan C. 2005. Cellular monitoring systems for the assessment of space environmental factors. Advances in Space Research 36:1673-1679.

Jin XD, Gong L, Guo CL, Hao JF, Wei W, Dai ZY, Li Q. 2008. Survivin expressions in human hepatoma HepG2 cells exposed to ionizing radiation of different LET. Radiation and Environmental Biophysics 47:399-404.

Li X, Zhao X, Fang Y, Jiang X, Duong T, Fan C, Huang CC, Kain SR. 1998. Generation ofdestabilized green fluorescent protein as a transcription reporter. Journal of Biological Chemistry 273:34970-34975

Löbrich M, Cooper PK, Rydberg B. 1996. Non-random distribution of DNAdouble-strand breaks induced byparticleirradiation. International Journal of Radiation Biology 70:493-503.

Matsuda A, Suzuki Y, Honda G, Muramatsu S, Matsuzaki O, Nagano Y, Doi T, Shimotohno K, Harada T, Nishida E, Hayashi H, Sugano S. 2003. Large-scale identification and characterization of human genes that activate NF-kappaB and MAPK signaling pathways. Oncogene 22:3307-3318.

Mehnati P, Morimoto S, Yatagai F, Furusawa Y, Kobayashi Y, Wada S, Kanai T, Hanaoka F, Sasaki H. 2005. Exploration of "over kill effect" of high-LET Ar- and Fe-ions by evaluating the fraction of non-hit cell and interphase death. Journal of Radiation Research (Tokyo) 46:343-350.

Mitra AK, Bhat N, Sarma A, Krishna M. 2005. Alteration in the expression of signaling parameters following carbon ion irradiation. Molecular and Cellular Biochemistry 276:169-173.

Mitra AK, Sarma A, Krishna M, Verma NC. 2004. Expression of NF-kappaB and ERK following heavy ion irradiation. Journal of Environmental Pathology, Toxicology and Oncology 23:53-59.

Monje ML, Toda H, Palmer TD. 2003. Inflammatory blockade restores adult hippocampal neurogenesis. Science 302:1760-1765.

Muscat S, Pelka J, Hegele J, Weigle B, Munch G, Pischetsrieder M. 2007. Coffee and Maillard products activate NF-kappaB in macrophages via $\mathrm{H}_{2} \mathrm{O}_{2}$ production. Molecular Nutrition \& Food Research 51:525-535.

Nakayama H, Ikebe T, Beppu M, Shirasuna K. 2001. High expression levels of nuclear factor kappaB, IkappaB kinase alpha and Akt kinase in squamous cell carcinoma of the oral cavity. Cancer 92:3037-3044.
National Aeronautics and Space Administration, USA (NASA). 2004. The vision for space exploration. Report NP-2004-01-334-HQ. Washington, DC: NASA Headquarters.

Natarajan M, Aravindan N, Meltz ML, Herman TS. 2002. Posttranslational modification of I-kappa B alpha activates NF-kappa B in human monocytes exposed to ${ }^{56} \mathrm{Fe}$ ions. Radiation and Environmental Biophysics 41:139-144.

National Council on Radiation Protection and Measurements (NCRP). 2006. NCRP Report No. 153: Information needed to make radiation protection recommendations for space missions beyond low-earth orbit. Bethesda, MD: NCRP Reports 153:1-427.

Nelson GA, Jones TA, Chesnut A, Smith AL. 2002. Radiation-induced gene expression in the nematode Caenorhabditis elegans. Journal of Radiation Research (Tokyo) 43(Suppl.):S199-203.

Ohnishi T, Takahashi A, Ohnishi K. 2002. Studies about space radiation promote new fields in radiation biology. Journal of Radiation Research (Tokyo) 43(Suppl.):S7-12.

Pecaut MJ, Gridley DS. 2010. The impact of mouse strain on iron ion radio-immune response of leukocyte populations. International Journal of Radiation Biology 86:409-419.

Rajagopal R, Waller AS, Mendoza JD, Wightman PD. 2008. The covalent modification and regulation of TLR8 in HEK-293 cells stimulated with imidazoquinoline agonists. Biochemical Journal 409:275-287.

Sasaki H, Yatagai F, Kanai T, Furusawa Y, Hanaoka F, Zhu WG, Mehnati P. 1997. Dependence of induction of interphase death of Chinese hamster ovary cells exposed to accelerated heavy ions on linear energy transfer. Radiation Research 148:449-454.

Shaw G, Morse S, Ararat M, Graham FL. 2002. Preferential transformation of human neuronal cells by human adenoviruses and the origin of HEK 293 cells. Federation of American Societies for Experimental Biology Journal 16:869-871.

Simon R, Samuel CE. 2007. Activation of NF-kappaB-dependent gene expression by Salmonella flagellins FliC and FljB. Biochemical and Biophysical Research Communications 355:280-285.

Skarsgard LD, Kihlman BA, Parker L, Pujara CM, Richardson S. 1967. Survival, chromosome abnormalities, and recovery in heavy-ion and $\mathrm{x}$-irradiated mammalian cells. Radiation Research (Suppl. 7): 208-221.

Sonenshein GE. 1997. Rel/NF-kappa B transcription factors and the control of apoptosis. Seminars in Cancer Biology 8:113-119.

Stoll U, Schmidt A, Schneider E, Kiefer J. 1995. Killing and mutation of Chinese hamster V79 cells exposed to accelerated oxygen and neon ions. Radiation Research 142:288-294.

Straube U, Berger T, Reitz G, Facius R, Fuglesang C, Reiter T, Damann V, Tognini M. 2010. Operational radiation protection for astronauts and cosmonauts and correlated activities of ESA Medical Operations. Acta Astronautica 66:963-973.

Tamatani T, Azuma M, Aota K, Yamashita T, Bando T, Sato M. 2001. Enhanced IkappaB kinase activity is responsible for the augmented activity of NF-kappaB in human head and neck carcinoma cells. Cancer Letters 171:165-172.

Tolkendorf E, Eichhorn K. 1983. Effect of ionizing-radiation of different linear energy-transfer on the induction of cellular death and of chromosome-aberrations in cells of the Chinese-hamster. Studia Biophysica 95:43-56.

Tsuchida Y, Tsuboi K, Ohyama H, Ohno T, Nose T, Ando K. 1998. Cell death induced by high-linear-energy transfer carbon beams in human glioblastoma cell lines. Brain Tumor Pathology 15:71-76.

Tsuruoka C, Suzuki M, Kanai T, Fujitaka K. 2005. LET and ion species dependence for cell killing in normal human skin fibroblasts. Radiation Research 163:494-500.

Whalen MK, Gurai SK, Zahed-Kargaran H, Pluth JM. 2008. Specific ATM-mediated phosphorylation dependent on radiation quality. Radiation Research 170:353-364.

Williams JR, Zhang Y, Zhou H, Osman M, Cha D, Kavet R, Cuccinotta F, Dicello JF, Dillehay LE. 1999. Predicting cancer rates in astronauts from animal carcinogenesis studies and cellular markers. Mutation Research 430:255-269.

Wu M, Lee $H$, Bellas RE, Schauer SL, Arsura M, Katz D, FitzGerald MJ, Rothstein TL, Sherr DH, Sonenshein GE. 1996. Inhibition of NF-kappaB/Rel induces apoptosis of murine B cells. European Molecular Biology Organization (EMBO) Journal 15:4682-4690.

Wulf H, Kraft-Weyrather W, Miltenburger HG, Blakely EA, Tobias CA, Kraft G. 1985. Heavy-ion effects on mammalian cells: Inactivation measurements with different cell lines. Radiation Research (Suppl. 8):S122-134. 
Yang TC, Blakely E, Chatterjee A, Welch G, Tobias CA. 1977. Response of cultured mammalian cells to accelerated krypton particles. Life Sciences and Space Research 15:169-174.

Yang TC, Craise LM, Mei MT, Tobias CA. 1985. Neoplastic cell transformation by heavy charged particles. Radiation Research (Suppl. 8):S177-187.

\section{Notice of correction}

This paper published online on 6 July 2011 contained an error. Figure $1 \mathrm{~A}$ was published twice instead of Figure 1B. This current version of the paper is the correct version. The publisher would like to apologize for the inconvenience caused.
Yatagai F. 2004. Mutations induced by heavy charged particles. Biological Sciences in Space 18:224-234.

Zabel U, Henkel T, Silva MS, Baeuerle PA. 1993. Nuclear uptake control of NF-kappa B by MAD-3, an I kappa B protein present in the nucleus. European Molecular Biology Organization Journal 12: 201-211. 